\title{
ORGANIZATION OF REMOTE DISTANCE LEARNING IN THE ARCTIC STATE INSTITUTE OF CULTURE AND ART OF YAKUTIA
}

\author{
ORGANIZAÇÃO DO ENSINO A DISTÂNCIA NO INSTITUTO DE CULTURA E ARTE \\ DO ESTADO ÁRTICO DE YAKUTIA
}

\author{
ORGANIZACIÓN DE LA EDUCACIÓN A DISTANCIA EN EL INSTITUTO DE \\ CULTURA Y ARTE DE YAKUTIA DEL ESTADO ÁRTICO
}

\author{
Olga Gerasimovna GOTOVTSEVA ${ }^{1}$ \\ Vladimir Polikarpovich BARAKHSANOV ${ }^{2}$ \\ Valentin Valentinovich CHERKASHIN ${ }^{3}$ \\ Maksim Andreevich ZAIKOV ${ }^{4}$ \\ Eduard Karlovich DANILOV ${ }^{5}$
}

ABSTRACT: This article presents the organization of remote distance learning in the Arctic State Institute of Culture and Art (ASICA) of the Republic of Sakha (Yakutia). It shows features of remote distance learning in ASICA based on the use of Moodle distance learning management system. The important thing for the functioning of the digital learning environment is the availability of resources: material and technical, human resources as teachers with formation in multimedia competencies in the software and modern technologies used. The survey result was shown regarding the availability of information within Moodle environment, which provides all types of classes and procedures for assessing learning outcomes whose implementation envisages the use of e-learning and distance learning technologies. The practical significance of the study lies in the specifics of training students future professionals of culture and art in the transition to remote distance learning.

KEYWORDS: Digital learning environment. Remote distance education. Moodle e-learning. Trainees.

RESUMO: Este artigo apresenta a organização do ensino à distância a distância no Instituto de Cultura e Arte do Estado Ártico (ASICA) da República de Sakha (Yakutia). Apresenta funcionalidades de ensino remoto a distância no ASICA baseado na utilização do sistema de gestão de ensino a distância Moodle. O importante para o funcionamento do ambiente digital

${ }^{1}$ Arctic State Institute of Culture and Art (UARCTIC), Yakutsk - Russia. Associate Professor of the Information Technology Department. Candidate of Pedagogical Sciences. ORCID: https://orcid.org/0000-0002-2275-8299. E-mail: olgagotovtseva@ro.ru

${ }^{2}$ North-Eastern Federal University named after M.K. Ammosov (NEFU), Yakutsk - Russia. Associate Professor of the Physical Education Department. Candidate of Pedagogical Sciences. ORCID: https://orcid.org/0000-00017648-6922. E-mail: vladimirbarakhsanov@yandex.ru

${ }^{3}$ Russia. Associate Professor of the Information Technology Department. ORCID: https://orcid.org/0000-00019927-8173. E-mail: v cherkashin@internet.ru

${ }^{4}$ Arctic State Institute of Culture and Art (UARCTIC), Yakutsk - Russia. Senior Lecturer of the Information Technology Department. ORCID: https://orcid.org/0000-0002-7367-6437. E-mail: m.zaikov@list.ru

${ }^{5}$ Arctic State Institute of Culture and Art (UARCTIC), Yakutsk - Russia. Senior Lecturer of the Information Technology Department. ORCID: https://orcid.org/0000-0002-7908-5478. E-mail: eduard-danilov@internet.ru

RPGE- Revista on line de Política e Gestão Educacional, Araraquara, v. 25, n. 2, p. 1239-1250, May/Aug. 2021. e-ISSN: 1519-9029 
de aprendizagem é a disponibilidade de recursos: materiais e técnicos, e recursos humanos, como professores com formação em competências multimidia nos softwares e tecnologias modernas utilizadas. O resultado da pesquisa foi demonstrado quanto à disponibilidade de informações no ambiente Moodle, que disponibiliza todo tipo de aulas e procedimentos de avaliação de resultados de aprendizagem, cuja implementação prevê a utilização de tecnologias de e-learning e educação a distância. O significado prático do estudo reside nas especificidades da formação de alunos - futuros profissionais da cultura e da arte na transição para o ensino a distância.

PALAVRAS-CHAVE: Ambiente digital de aprendizagem. Educação à distância. Moodle elearning. Estagiários.

RESUMEN: Este artículo presenta la organización del aprendizaje a distancia en el Instituto Estatal Ártico de Cultura y Arte (ASICA) de la República de Sakha (Yakutia). Muestra las características de la enseñanza a distancia en ASICA basada en el uso del sistema de gestión de la enseñanza a distancia Moodle. Lo importante para el funcionamiento del entorno de aprendizaje digital es la disponibilidad de recursos: materiales y técnicos, recursos humanos de los profesores con competencias multimedia formadas en el software y las tecnologías modernas utilizadas. El resultado de la encuesta se mostró en relación con la disponibilidad de información dentro del entorno Moodle, que proporciona todo tipo de clases y procedimientos para evaluar los resultados del aprendizaje cuya implementación prevé el uso de tecnologías de aprendizaje electrónico y a distancia. La importancia práctica del estudio radica en las particularidades de la formación de los estudiantes, futuros profesionales de la cultura y el arte, en la transición a la enseñanza a distancia.

PALABRAS CLAVE: Entorno digital de aprendizaje. Educación a distancia. Moodle elearning. Aprendices.

\section{Introduction}

The modern development stage of information society and education is characterized by mastering high-tech computer tools that should be included in the training for specialists in every field, including culture and art. The relevance of the distance learning implementation based on e-learning is confirmed by the Strategy for the Development of the Information Society in the Russian Federation for 2017-2030 (RUSSIA, 2018). The Federal Educational Standard $3++$ requires students to master the important professional competence that facilitates the fast retrieval, analysis, and public presentation of research results using computer technology. The formation of this competence will be successful if based on the use of modern educational technologies and computer technology, the Internet, and the introduction of new methods and techniques in the field of professional activity (BARAKHSANOV; DANILOVA, 2018; BAZAROVA; SOLOVYOVA, 2018).

RPGE- Revista on line de Política e Gestão Educacional, Araraquara, v. 25, n. 2, p. 1239-1250, May/Aug. 2021. e-ISSN: 1519-9029 
The formation of a digital educational environment is one of the key conditions for ASICA staff training in the transition to distance learning (BATOROV, 2012). ASICA is the basic, and the only regional, university in Russia which trains staff in the field of culture and arts for the largest region of Russia - the North-East of the Arctic zone. ASICA is one of the well-known leaders in the training of creative staff of native Arctic minorities. The specifics of the content of the educational programs, based on the connection of academic arts with the cultural traditions of Arctic peoples, became the key to the attractiveness of the institute for the youth of the regions of the North, Siberia, and the Far East (LEVERIEVA; BATOROV, 2009).

It should be noted that ASICA carries out its activities considering social and cultural development of the Republic of Sakha (Yakutia) related to natural and climatic conditions of the North, traditional economy and life support system, material and spiritual culture, influencing the mentality and ethnic identity of young people. This actualizes the problems of fulfilling the social order for the staffing of specialists in culture and art in the conditions of bilingualism of the educational process.

The paper aims at evaluating the Moodle distance learning management system to determine the level of access to the posted information on academic disciplines. It will help to develop a strategy for the formation of a digital educational environment at the institute by updating the information and communication infrastructure, training, creating a digital platform, systematic improvement of quality and expanding opportunities for continuing education for all categories of teachers and staff.

\section{Literature review}

The COVID-19 pandemic has accelerated the rate of implementation of remote distance learning and thereby opened the challenges and prospects for e-learning development (BARAKHSANOVA et al., 2020; SÁ; SERPA, 2020; PRATIWI, 2020). Researchers from different countries conduct multidimensional research on the creation and development of educational digital ecosystems, their infrastructure and purpose. Legan, Royak and Gorbunov (2020) define a separate area, which deals with the design and creation of digital educational ecosystems. Li and Wang (2021), Rieber (2017) and Luo, Zhang and Qi (2017) note that the prerequisites for creating digital ecosystems are the theoretical and practical results obtained by researchers of the scientific and pedagogical community on distance and e-learning. 
Rizal, Rusdiana and Setiawan (2019) and Hernández, Cumpa and Rodríguez (2018) focus on the research of digital training of teachers as direct and active participants of the digital educational process carried out in a digital educational environment.

Similar studies have been conducted by Sá and Serpa (2020), who point out the need to improve the digital sustainability of higher education by participating in the elimination of the pandemic consequences. Works of Greenhow, Cathy Lewin, and Willet (2020) reflect the problems of digital inequality of low-income families, the transfer of responsibility for the education of children from schools to parents. At the same time, the analyzed papers failed to fully reflect the works that consider the specifics of regional education for the organization of remote distance learning in extreme conditions.

Given the international experience, Russian scientists during the pandemic actively researched the problems in the field of education digitalization. They identified different approaches in the implementation of online learning (PROKOPIEV et al., 2020; MIRONENKO, 2019), highlighted the important role of the electronic educational environment of the university as the basis for digitalization of education (KOSTIKOVA et al., 2020; VLASOVA et al., 2019a; VLASOVA; BARAKHSANOVA, 2019) and the transformation of teacher education during the pandemic (VLASOVA et al., 2019b). They investigated the digitalization of teachers colleges and teaching specialties (VLASOVA et al., 2020) and the transition from an educational environment to an educational ecosystem (KUSHNIR, 2019; FEDOROV, 2019).

The problems of regional universities on the formation and development of the electronic educational environment, the introduction of IT and software tools in the educational process are reflected in the works of Barakhsanova (2019), Bazarov and Solovyov (2018). Sakulich (2017) studied the formation of competencies in information and communication technologies of university students in the digital revolution in terms of ensuring the preservation of the documentary heritage of the peoples of Yakutia. The problem of digitizing manuscripts of rare books, film and photo documents was studied to solve the problem of remote distance learning organization during the pandemic (LEVERIEVA; BATOROV, 2009).

\section{Materials and methods}

A set of measures has been taken to ensure the transition of ASICA to remote distance learning in the conditions of COVID-2019 spread, including the involvement and mastery of 
students and teachers with ZOOM technology, the formation of a digital educational environment ASICA, creation of an organizational management structure and control of training sessions using the Moodle environment. Students (400 persons) and educators (50 persons) of ASICA participated in the study.

In order to solve the set tasks, the following research methods were used: analysis, generalization, and systematization of the experiment with the use of questionnaires to identify the level of students' involvement in the Moodle environment. The reliability and validity of the results are ensured by using methods of recording and analysis of empirical material.

While grading a multiple-choice text question, an equilibrium grading system is used. The weight of the answer is determined by the formula: $\mathrm{W}=\mathrm{B}_{\max } / \mathrm{N}=100 \% / \mathrm{N}$, where $\mathrm{B}_{\max }-$ maximum score for the answer to the given question, $N$ is the total number of answers to the question. The result is calculated in the following way: weight is added for each correct answer and subtracted for each incorrect one.

$\mathrm{W}_{\text {total }}=\sum W_{\text {right }}-\sum \mathrm{W}_{\text {wrong }}$ where $\mathrm{W}=\mathrm{W}_{\text {wrong }}=\mathrm{W}_{\text {right }} ; \mathrm{W}_{\text {right }}-$ a point for a correct answer (the answer is correct if it is correct and selected, and when it is incorrect and not selected);

$\mathrm{W}_{\text {wrong }}$ - a point for an incorrect answer (the answer is incorrect if the it is correct but not chosen, and when it is incorrect but chosen). Then this sum is normalized (the range of points $[-100 ; 100]$ is brought to the range $[0 ;+100])$ :

$$
\mathrm{W}=\mathrm{W}_{\text {total }}+100 / 2 \text {. }
$$

The maximum score $(100 \%)$ is if all correct answer options, and only if they are marked. The calculation example contains 2 correct and 2 incorrect answers out of 4 answer options. When answering this question one correct and one incorrect answer was chosen. The weight of each of the answers to the question is $\mathrm{W}=\mathrm{B}_{\max } / \mathrm{N}=100 \% / 4=25 \%$.

The calculation is done as follows: $\mathrm{W}_{\text {total }}=25 \%$ (for correct selected answer) $+25 \%$ (for incorrect unselected one) - 25\% (for correct unselected one) - 5\% (for incorrect selected one) $=0 \%$. 


\section{Results}

Specific test questions were developed for three large studies. The first study involved freshmen. The questionnaire for students included 21 questions of different orientations. All aspects of the distance learning environment were covered as much as possible: user activity, a general idea of an Internet user, and methods of distance learning in the educational process based on the Moodle environment and other digital tools. The results of this study provided insight into how freshmen use the Internet in basic academic disciplines.

The second stage was a study among students with a total sample of 400 students from 10 departments of ASICA. For this study, the questionnaire was revised and included 30 questions of both sociological and psychological orientation. It included questions determining the user activity of students and its content features, perceptions of remote distance learning, awareness of digital resources, as well as special methods and training technologies: the methodology of using distance and electronic learning; the methodology to determine the level of formation of information and digital competence, and several open questions, allowing for a qualitative analysis of the attitude towards remote distance learning.

The third stage was aimed at ASICA teachers. Within this study, 50 teachers, both users, and non-users of the Internet were surveyed. The test included questions aimed at finding out teachers' opinions on the use of distance technologies by students, to determine the level of control of students in the use of digital tools in academic disciplines.

The questionnaire included 30 questions covering the following aspects: the teacher's Internet activity and its content, perceptions of the purposes for which students use the Internet, the motive for its use, assessment of Internet freedom, emotional perception of the Internet, and others. This test, like the student questionnaire, included some questions to identify this area during the study. Students were asked specific questions to indicate the area of application of Internet resources and technologies that they would like to improve and develop.

All students would like to participate in groups to develop projects related to the use of network technologies with free applications. $82 \%$ of students choose to work with video content as the basis of their activities: editing, creating streams and screencasts. The second place was taken by web programming $-35 \%$ and; the third - by layout and design of printed information. These results indicate the formation of motivation for the use of Internet technologies in future professional activities. 
$92 \%$ of the experiment participants prefer to use modern educational technologies, especially the Moodle environment in their professional activities.

Survey responses from teachers and students associated with the field of preference for network technology gave the following results: developmental learning (25\%), classical $(20 \%)$; informational $(54 \%)$, as well as a significant number of respondents highlighted the efficiency of digital tools and Internet resources. In order to find out the students' readiness to use new training tools, some questions were asked about the benefits of remote distance learning in academic disciplines. The survey questions tried to identify the needs of teachers and students in the use of specific Internet resources and technologies. The survey revealed that $75 \%$ of teachers feel the need to improve information competence related to remote distance learning. This is due to the active introduction of network technologies in all areas of student activities. Despite the widespread dissemination of courses for independent study and use of applications, they are not sufficient, and $55 \%$ of teachers note the need to study this area in the use of applications in professional activities.

On average, the use of digital tools, including Moodle and the Internet, by teachers and students improved by $72 \%$ and $38 \%$, respectively.

A generalized analysis of the tests shows that the implementation of remote distance learning in the educational process is so rapid that it is difficult to be researched by teachers during the pandemic, and it should be noted that the subject field of research on the organization of distance learning should begin in the preparation of professional activities of students, considering the informatization of education.

Next, a check was implemented on the attendance of ASICA students and teachers in the Moodle electronic educational environment at ysaa.ru, which exhibits the class (for the discipline). The op-lin exhibits tests and educational and methodological materials of the library http://moodle.ysaa.ru/, where it is convenient to monitor the activities of both the teacher and the student.

To identify the level of user skills and track attendance, an analysis of the quality of electronic documentation (logbook) of students in the Moodle system was conducted, which shows faculty members who are interested in learning through the university website

According to the data, for one month of 13/04/2020-19/03/2020, the website recorded 4078 students from 7 departments of ASICA, and for the period 20/02/2021-20/03/2021, the website recorded 2.5 times more visits; the dynamics is shown in Figure 1. 
Figure 1 - Moodle site statistics for one month from 13/04/2020 to 13/05/2020 and from $20 / 02 / 21$ to

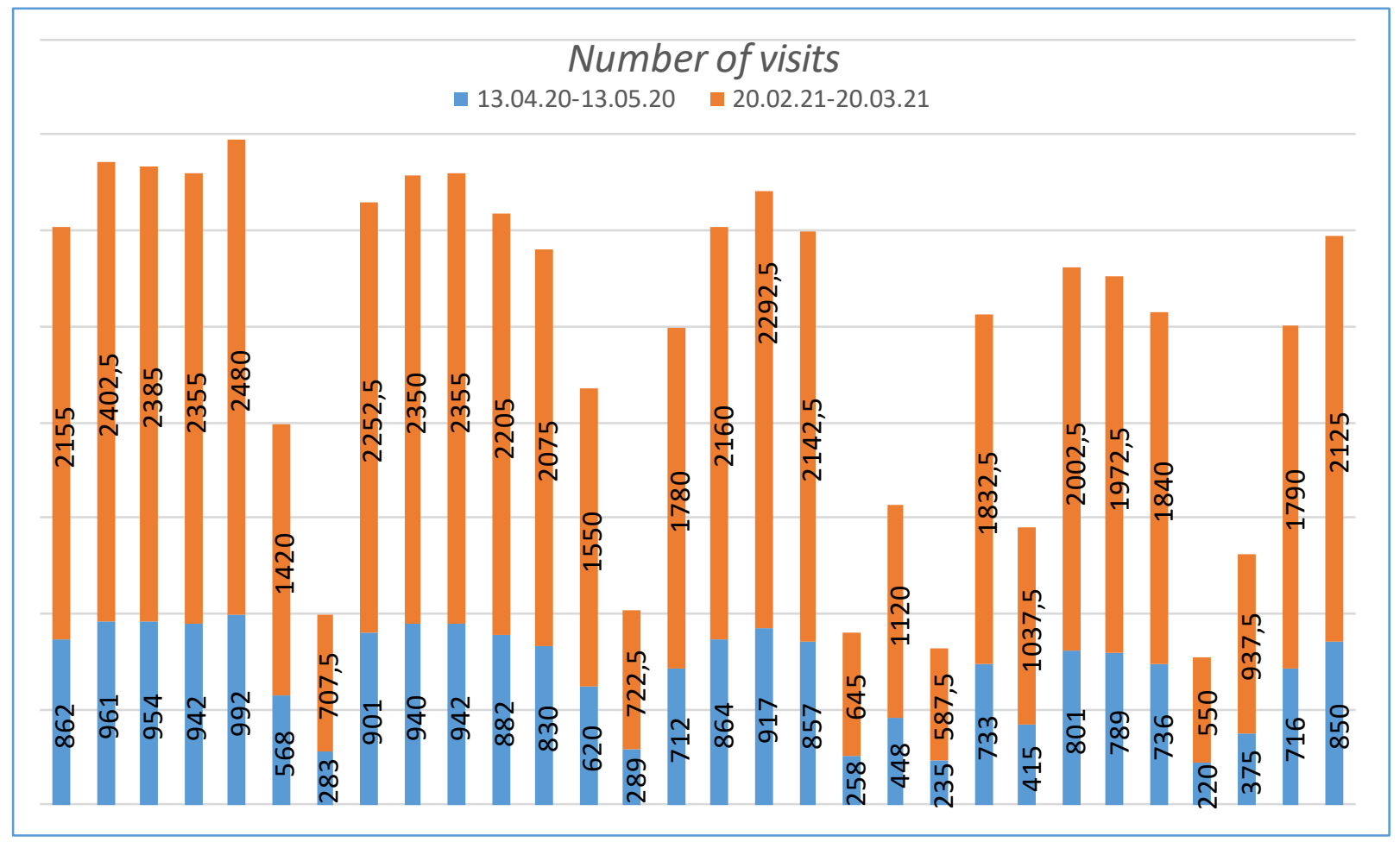

Source: Prepared by the authors

Many students visit the site to view no more than one page, and that is mostly the home page. Most visitors enter purposefully, not randomly. It should be noted that the contingent of ASICA students is mostly graduates of rural schools and remote Arctic regions of the republic. Therefore, during the study, we considered all features of distance learning. Due to the specifics of our educational environment in the republic, a special need for distance education arises in remote areas.

\section{Discussion}

It has been found that to organize remote distance learning it is necessary to modernize the educational, methodological, and technological support of training sessions. Current difficulties in the development of didactic materials on the methodology of online learning have been determined. The choice of a digital tool - the use of Moodle environment - has been specified.

Analysis of the study shows that remote distance learning will contribute to an increase in the number of developed electronic video lectures and practical exercises with teaching materials for academic disciplines.

RPGE- Revista on line de Política e Gestão Educacional, Araraquara, v. 25, n. 2, p. 1239-1250, May/Aug. 2021. e-ISSN: 1519-9029 
The introduction of new technologies in education will facilitate the development of an electronic textbook with multimedia fragments and the use of external electronic resources, as well as the use of cloud technology and technological innovations in the educational process.

Thus, it is necessary to justify and develop the concept and innovative model of methodological and information and technological support of remote access to training based on the use of digital tools and also to consider the specifics of training students in institutes of culture and art in the regions of Russia.

\section{Conclusion}

The challenging events in 2020-2021 have given a strong impetus to the development of distance learning at ASICA. It is remote distance learning that allows the training of students who live far away or for a variety of reasons cannot attend face-to-face classes. At the moment, the Institute has different ways of communication with teachers and tutors, mainly through the Moodle environment and online resources as Zoom, Skype, and e-mail.

Distance learning requires students to have strong motivation and strict self-discipline, developed willpower, responsibility, and self-organization, which in turn are necessary to help maintain the desired rate of learning without outside control, independently, which not all students manage.

In the remote form of distance learning, it is always possible to come back to the study of the topic, for example, to re-watch a video recording of the lesson, repeat the theoretical material, and consolidate knowledge. Such a possibility is a significant advantage, as it increases the chances of successful completion of training.

Summarizing, it should be noted that the forced transition to remote distance learning in a period of self-isolation allowed each teacher to review their competencies in the field of digital technology and tools through self-education, trial and error to improve skills, build an individual system of work in a remote format, expand teaching capabilities through the use of a wide range of modern digital electronic resources in educational activities.

\section{REFERENCES}

BARAKHSANOVA, E. A. et al. Transdisciplinary approach to training future managers for digital education in Yakutia. Propositos y Representaciones, v. 8, n. 3, e702, 2020. 
BARAKHSANOVA, E. A. Methodological support for e-learning implementation in a pedagogical university. In: Intellectual technologies: humanitarian, social and legal and digital aspects. Materials of the all-Russian scientific-practical conference with international participation. 2019. p. 89-94.

BATOROV, A. R. Multimedia applications as an effective tool to support the learning process in the information and educational environment of the university of culture. Information and communication technologies and electronic resources in the system of cultural and civilizational transformations: the experience and problems of use in universities of culture and arts. Chelyabinsk, 2012. p. 208-214.

BAZAROVA, T. S.; SOLOVYOVA, R. A. To the problem of forming the ICTcompetence of future engineers in the information and educational environment of the university. Ulan-Ude: Publishing house of the Buryat State University, 2018. p. 99-103.

FEDOROV, I. M. Transition from educational environment to educational ecosystem. Young Scientist, n. 28, p. 246-250, 2019.

GREENHOW, C.; LEWIN, C.; WILLET, K. B. S. The educational response to Covid-19 across two countries: a critical examination of initial digital pedagogy adoption. Technology, Pedagogy and Education, v. 30, n. 1, p. 7-25, 2020. DOI:

doi.org/10.1080/1475939X.2020.1866654

HERNÁNDEZ, R. M.; CUMPA, R. O.; RODRÍGUEZ, S. Q. New ways of learning: teacher training in the use of ICTs. Propósitos y Representaciones, v. 6, n. 2, p. 671-701, 2018. DOI: dx.doi.org/10.20511/pyr2018.v6n2.248

KOSTIKOVA, N. A. et al. The didactic potential of university electronic information and educational environment in the context of a pandemic. Propósitos y Representaciones, v. 8, n. 3, e707, 2020. DOI: doi.org/10.20511/pyr2020.v8nSPE3.707

KUSHNIR, M. E. et al. Educational logistics in digital school. Informatics and Education, n. 9, p. 5-11, 2019. DOI: doi.org/10.32517/0234-0453-2019-34-9-5-11

LEGAN, M. V.; ROYAK, M. E.; GORBUNOV, M. A. DiSpace 2.0 e-learning system - a fundamental element of the digital educational environment (ecosystem) of NSTU. Professional Education in the Modern World, v. 10, n. 1, p. 3520-3531, 2020. DOI: doi.org/10.15372/PEMW20200115

LEVERIEVA, G. F.; BATOROV, A. R. Preservation of documentary heritage of the peoples of the Republic of Sakha (Yakutia). Library and Information Science, n. 3, p. 34-39, 2009.

LI, F.; WANG, L. Empirical Analysis of Return to Distance Higher Education in Different Disciplines. The International Review of Research in Open and Distributed Learning, v. 22, n. 1, p. 148-165, 2021. DOI: doi.org/10.19173/irrodl.v22i1.5029

LUO, N.; ZHANG, M. L.; QI, D. Effects of different interactions on students' sense of community in e-learning environment. Computers \& Education, v. 115, p. 153-160, 2017. DOI: doi.org/10.1016/j.compedu.2017.08.006 
MIRONENKO, E. C. Digital educational environment: the concept and structure. Social Space, n. 4, p. 6, 2019.

PRATIWI, W. R. The practice of digital learning (D-Learning) in the study from home (SFH) policy: teachers' perceptions. Journal of Southwest Jiaotong University, v. 55, n. 4, 2020. DOI: 10.35741 /issn.0258-2724.55.4.17

PROKOPIEV, M. S. et al. Development of a programming course for students of a teacher training higher education institution using the programming language Python. Propósitos $\mathbf{y}$ Representaciones, v. 8, n. 3, 2020. DOI: dx.doi.org/10.20511/pyr2020.v8n3.484

RIEBER, L. P. Participation patterns in a massive open online course (MOOC) about statistics. British Journal of Educational Technology, v. 48, n. 6, p. 1295-1304, 2017. DOI: doi.org/1010.1111/bjet.12504

RIZAL, R.; RUSDIANA, D.; SETIAWAN, W. Digital literacy of preservice science teacher. Journal of Physics: Conference Series, v. 1157, n. 2, 022058, 2019. DOI: doi.org/1010.1088/1742- 6596/1157/2/022058

RUSSIA. Priority project "Modern Digital Educational Environment in the Russian Federation". Ministry of Science and Higher Education: official website. 2018. Available: http://government.ru/projects/selection/643/. Access: 10 Dec. 2020.

SÁ, M. J.; SERPA, S. The covid-19 pandemic as an opportunity to foster the sustainable development of teaching in higher education. Sustainability, Switzerland, v. 12, n. 20, p. 116, 2020. DOI: doi.org/10.3390/su12208525

SAKULICH, N. B. Formation of ICT-competences of university students in the conditions of digital revolution. Pedagogical Journal, v. 7, n. 2A, p. 302-314, 2017.

VLASOVA, E. Z. et al. Artificial intelligence. The area of adaptive possibilities for methodological innovations in pedagogic education. Contemporary Dilemmas: Education, Politics and Values, v. 7, n. 10, C. 9, 2019b.

VLASOVA, E. Z. et al. Digital transformation of the pedagogical education in the Russian Federation. Contemporary Dilemmas: Education, Politics and Values, v. 7, n. 10, C. 52, 2019a.

VLASOVA, E. Z. et al. Teacher education in higher education systems during pandemic and the synergy of digital technology. Propósitos y Representaciones, v. 8, n. 3, e 719, 2020. DOI: dx.doi.org/10.20511/pyr2020.v8nSPE3.719

VLASOVA, E. Z.; BARAKHSANOVA, E. A. Innovative solutions of teacher training for Northern regions to the use of e-learning. The Emissia, n. 9, p. 2762, 2019. 


\section{How to reference this article}

GOTOVTSEVA, O. G; BARAKHSANOV, V. P.; CHERKASHIN, V. V.; ZAIKOV, M. A.; DANILOV, E. K. Organization of remote distance learning in the Arctic State Institute of Culture and Art of Yakutia. Revista on line de Política e Gestão Educacional, Araraquara, v. $25, \quad$ n. 2 , p. 1239-1250, May/Aug. 2020. e-ISSN:1519-9029. DOI: https://doi.org/10.22633/rpge.v25i2.15315

Submitted: $10 / 05 / 2021$

Required revisions: $25 / 06 / 2021$

Approved: $20 / 07 / 2021$

Published: 01/08/2021 